Objectives: The aims of this study were to evaluate $\mathrm{AMH}$ serum levels in a cohort of young adult women affected from JIA, to compare these levels between patients and healthy controls and to assess whether the presence of the disease and the influence of previous exposure to disease-modifying antirheumatic drugs (DMARDs) and of other disease parameters may affect the ovarian reserve. Methods: Forty women with a diagnosis of JIA, aged 18 to 25 years and with regular menses, and 20 healthy women age-matched were evaluated. Anti-Müllerian Hormone serum levels were measured according to a 2-stage enzyme-linked immunosorbent assay (ELISA) technique using a commercially available kit (AMH Gen II ELISA; Beckman Coulter). Clinical and demographic characteristics, disease duration, previous and current therapies disease activity score on 44 joints (DAS), health assessment questionnaire (HAQ) were performed at the time of blood sample.

Results: JIA patients had a mean age of $21.4 \pm 3.2$ years, a disease duration of $11.5 \pm 6.6$ years, a DAS of $1.22 \pm 0.58$, and $12(30 \%)$ were smokers. No significant differences were found in our cohort of JIA and healthy subjects in AMH serum levels $(5.6 \pm 0.4$ vs $6.6 \pm 0.6 \mathrm{ng} / \mathrm{ml}$, respectively, $\mathrm{p}=0.5$ ).

Considering the JIA cohort, 23 patients $(57.4 \%)$ were treated with methotrexate (MTX) for a mean period of $2.1 \pm 3.1$ years and $20(50 \%)$ with anti-TNF drugs for $4.3 \pm 2.3$ years. Twelve JIA women $(30 \%)$ were treated with both MTX and anti-TNF. No correlations were found between AMH serum levels and patients age $(p=0.6)$, disease duration (years) $(p=0.67)$ and duration of therapy with MTX $(p=0.5)$ or anti-TNF $(p=0.11)$.

Dividing JIA patients according to MTX use, no differences were observed between MTX users and non users patients in AMH levels $(6.0 \pm 0.5$ vs $5.1 \pm 0.5 \mathrm{ng} / \mathrm{ml}$, respectively, $p=0.22$, age, disease duration and other clinical characteristics. Patients expose to anti-TNF had AMH serum levels tendentially higher then non users patients $(6.3 \pm 0.6$ vs $4.9 \pm 0.5 \mathrm{ng} / \mathrm{ml}$, respectively $p=0.07)$.

Conclusions: In our JIA group of young adult JIA women, ovarian reserve seems not be changed by the presence of the disease, the long disease duration and the use of immunosuppressive drugs. These findings could be important for adult JIA patients.

References:

[1] Ostensen M et al. J Rheumatology 2000;27:1783-7.

Disclosure of Interest: None declared

DOI: 10.1136/annrheumdis-2017-eular.4761

\section{THU0500 PHOTOBIOSTIMULATION OF CHRONIC CERVICAL PAIN IN JUVENILE POLYARTHRITIS}

C. Ailioaie, L.M. Ailioaie. Dept. of Medical Physics, Iasi, Romania, "Al. I. Cuza" University, lasi, Romania

Background: Chronic pain management in juvenile arthritis constitutes a special provocation not only for the medical doctors, but also for the patients and parents. Despite the extensive use of the biological agents with high efficacy, combined with the multimodal therapies, chronic pain still remains an important issue for the public health, with implications on the activities of daily living and the scholar performances. Lasers could be used for transmitting biological messages and initiating metabolic changes within living cells: no more pain, much more energy, will contribute to muscular and joints repair.

Objectives: Aim of the present study was to evaluate the effects of photobiostimulation combined with DMARDs in patients with juvenile polyarthritis and chronic cervical pain.

Methods: 62 patients diagnosed with juvenile polyarthritis (ILAR criteria), 11.4 years mean age were randomly divided in Group I (42 patients treated with local laser biostimulation and methotrexate), comparatively with a Group II - control (20 patients) treated with methotrexate and placebo laser, for a period of 9 months. Group I received local laser biostimulation with a dose of $2.5 \mathrm{~J} / \mathrm{cm}^{2}$ in 14 latero-cervical painful points, corresponding to the 7 cervical vertebrae, 1 point on the insertion of sternocleido-mastoidian muscle on the styloid processus, and 1 point on each loco-regional submandibular lymphatic ganglions, using a GaAIAs laser probe of $670 \mathrm{~nm}, 25 \mathrm{~mW}$ output power and a modulation frequency of $10 \mathrm{~Hz}$. 45 joules were applied daily as laser treatment, 10 sessions per month, repeated 3 times, in the 9 months. For all the patients, the main medication was methotrexate in a dose of $0.6 \mathrm{mg} / \mathrm{kg}$ (maximum $20 \mathrm{mg}$ ) per week, steroids and symptomatic drugs, when necessary. Tutors and the older children have signed the informed consent. Measurement of the subjective pain was on VAS $(0-100$ $\mathrm{mm}$ ), and objective pain was assessed with an electronic device, the Algometer Commender. The range of motion for flexion/extension, and the rotation to the left/right of the cephalic extremity was measured with Dualer IQ Inclinometer.

Results: In the end of study, the level of chronic pain estimated with Commander Algometer decreased by $74.6 \%$ in Group I, compared with only $41 \%$ in the control Group, and the range of motion in the affected cervical segment assessed with Dualer Inclinometer increased by $66 \%$ in the first Group, compared with only $34 \%$ in placebo group.

Conclusions: Laser biostimulation proved to be an effective method for the complex management of chronic pain in juvenile polyarthritis.

References:

[1] Ravelli A, Martini A. Juvenile idiopathic arthritis. Lancet. 2007;369:767-778.

[2] Ravelli $A$, et al. Oral versus intramuscular methotrexate in juvenile chronic arthritis. Clin Exp Rheumatol. 1998;16:181-83.

[3] Ailioaie LM, Litscher G, Weber M, Ailioaie C, Litscher D, Chiran DA. Innovations and Challenges by Applying Sublingual Laser Blood Irradiation in Juvenile Idiopathic Arthritis. International Journal of Photoenergy 2014(2):1-8, June 2014. DOI: $10.1155 / 2014 / 130417$.

[4] Ailioaie C, Lupusoru-Ailioaie LM. Beneficial effects of laser therapy in the early stages of rheumatoid arthritis onset. Laser Therapy.1999;Vol. 11-2, 79-87.

Disclosure of Interest: None declared

DOI: 10.1136/annrheumdis-2017-eular.6831

\section{THU0501 EFFICACY AND SAFETY OF METHOTREXATE AS MAINTENANCE THERAPY FOR CHILDREN WITH ANTI-N-METHYL-D-ASPARTATE RECEPTOR (NMDAR) ENCEPHALITIS: EXPERIENCE OF A SINGLE CENTER}

D. Ramos-Bello, A.N. Rangel-Botello, G. Aguilera Barragan-Pickens,

T.A. Luna-Zúñiga, A.J. Pedro-Martínez, G. Martínez-Flores, A. Bravo-Oro,

C. Abud-Mendoza. Unidad regional de Reumatología y Osteoporosis, Hospital Central "Dr. Ignacio Morones Prieto" y Facultad de Medicina de la UasIp, SLP, SLP, Mexico

Background: Autoimmune-mediated encephalitis (A-ME) in children remains as a diagnostic and therapeutic challenge (1). These patients have a $12 \%$ risk of relapse, which is usually more severe (2). We previously proposed the therapy with methotrexate (MTX) for this condition (3), and we are offering now additional data on its potential benefits.

Objectives: To describe the outcome of children with A-ME receiving MTX for at least one year after stabilization of symptoms.

Methods: In this retrospective study we recruited 11 patients (7 females) with A-ME, a mean age of 7.5 years (range 8 months - 14 years), and with a median follow up of 22 months. In all cases, anti-NMDAR antibodies (subunit NR1) were detected in the CSF. Data from these patients were collected by consulting medical records. Relapse of encephalitis was defined as new onset of symptoms occurring after at least 2 months of remission, in the absence of other CNS disease.

Results: Patients presented with seizures $(n=10)$, behavioral changes $(n=11)$, psychosis $(n=11)$, speech problems $(n=10)$, and autonomic/breathing dysregulation $(n=9)$. Patients were initially treated with methylprednisolone pulses $(n=11)$, rituximab $(n=6)$, intravenous immunoglobulins $(n=4)$, cyclophosphamide $(n=3)$ and MTX $(n=11)$. Complete remission was observed in all cases, and maintenance therapy with MTX (10 mg/m² BSA) was started in all them, with gradual tapering until it was stopped. Interestingly, no relapses have been observed in any case during the mean follow up. One patient had mild oral ulcers and other showed mild elevation of liver enzymes; both events remitted after discontinuing the treatment for a couple of weeks.

Conclusions: Since relapses in patients with A-ME are a relatively frequent, the immunosuppressive therapy to prevent them is fully justified (4). Moreover, MTX therapy in pediatric patients is safe and usually well tolerated $(3,5,6)$. The recommended dose is less than $15 \mathrm{mg} / \mathrm{m}^{2}$ BSA or $1 \mathrm{mg} / \mathrm{kg}$, with a maximal dose of $40 \mathrm{mg}$ and with folic acid supplementation. In this regard, our study suggests that MTX administration $\left(10 \mathrm{mg} / \mathrm{m}^{2} \mathrm{BSA}\right)$ during at least one year is a viable and effective therapy for maintenance treatment of A-ME. Accordingly, we did not detect relapses in the 11 patients studied with a median follow up time of 22 months and with an acceptable safety profile.

References:

[1] AlHakeem AS, et al. Neurosciences (Riyadh). 2017;22:67-68.

[2] Titulaer MJ, et al. Lancet Neurol. 2013;12:157-165.

[3] Bravo-Oro A, et al. Rev Neurol. 2013:57:405-410.

[4] Lin JJ, et al. Pediatr Neurol. 2014;50:574-80.

[5] Weibel L, et al. Br J Dermatol. 2006:155:1013-20.

[6] Li SC, et al. Arthritis Care Res. 2012;64:1175-1185.

Disclosure of Interest: None declared

DOI: 10.1136/annrheumdis-2017-eular.2726

\section{THU0502 EFFICACY AND SAFETY OF CANAKINUMAB IN PATIENTS WITH STILL'S DISEASE: A POOLED ANALYSIS OF SJIA DATA BY AGE GROUPS}

E. Feist $^{1}$, P. Quartier ${ }^{2}$, B. Fautrel ${ }^{3}$, R. Schneider ${ }^{4}$, P. Sfriso ${ }^{5}$, P. Efthimiou ${ }^{6}$, L. Cantarini ${ }^{7}$, K. Lheritier ${ }^{8}$, K. Leon ${ }^{9}$, C. Karyekar ${ }^{9}$, A. Speziale ${ }^{8}$.

${ }^{1}$ Charite-Universitätsmedizin, Berlin, Germany; ${ }^{2}$ Necker-Enfants Malades Hospital; ${ }^{3}$ Pitie Salpetriere Hospital, Paris, France; ${ }^{4}$ PRCSG, Cincinnati, United States, ${ }^{5}$ University of Padova, Padova, Italy; ${ }^{6}$ Weill Cornell Medical College, New York, United States; ${ }^{7}$ University of Siena, Siena, Italy; ${ }^{8}$ Novartis Pharma AG, Basel, Switzerland; ${ }^{9}$ Novartis Pharmaceuticals Corporation, East Hanover, United States

Background: Still's disease presents in paediatric and adult patients (pts) as a disease continuum with similar symptoms and pathophysiology. ${ }^{1,2}$

Objectives: To evaluate the efficacy and safety of canakinumab (CAN), a selective human anti-IL1 $\beta$ monoclonal antibody, in SJIA pts from pooled data across 3 age groups (grps): children, adolescent and adults (the latter representing adult-onset Still's disease [AOSD] population)

Methods: Data of CAN treated pts were pooled from 4 SJIA studies (NCT00426218, NCT00886769, NCT00889863, NCT00891046). CAN was ad- 
ministered at $4 \mathrm{mg} / \mathrm{kg}$ every 4 weeks (wk). Efficacy parameters (adapted ACR [aACR] paediatric responses, juvenile idiopathic arthritis [JIA] ACR responses, pts with inactive disease), CRP levels over 12 wk and safety were assessed by age grp. One study [NCT00426218] was excluded for efficacy outcomes.

Results: 216 children $(2-<12$ years [y]), 56 adolescents $(12-<16$ y) and 29 adults $(\geq 16 \mathrm{y})$ were analysed for efficacy outcomes. The efficacy parameters across the 3 age grps were largely comparable (Table 1). The safety profile of CAN was similar across age grps (Table 2). One death was reported (adolescents grp). Clinical, laboratory and immunogenicity data showed no notable differences between the age grps.

Table 1. Responses by age grp and time point

\begin{tabular}{|c|c|c|c|c|c|}
\hline \multirow[t]{2}{*}{ Age group } & \multirow[t]{2}{*}{$\%$} & \multicolumn{2}{|c|}{ aACR paediatric; $\mathrm{n} / \mathrm{N}(\%)$} & \multicolumn{2}{|c|}{ JIA ACR; n/N (\%) } \\
\hline & & Day 15 & Day 85 & Day 15 & Day 85 \\
\hline \multirow[t]{3}{*}{ Children } & $\geq 30$ & 158/216 (73.1) & $90 / 133(67.7)$ & 169/216 (78.2 & $93 / 133$ (69.9) \\
\hline & $\geq 70$ & $109 / 216(50.5)$ & 77/133 (57.9) & $111 / 216(51.4)$ & 77/133 (57.9) \\
\hline & $\geq 100$ & $46 / 216(21.3)$ & $42 / 133(31.6)$ & $47 / 216(21.8)$ & $42 / 133(31.6)$ \\
\hline \multirow[t]{3}{*}{ Adolescents } & $\geq 30$ & $47 / 56(83.9)$ & $20 / 27(74.1)$ & $47 / 56(83.9)$ & $20 / 27(74.1)$ \\
\hline & $\geq 70$ & $33 / 56(58.9)$ & $18 / 27(66.7)$ & $33 / 56(58.9)$ & $18 / 27(66.7)$ \\
\hline & $\geq 100$ & $15 / 56(26.8)$ & $8 / 27(29.6)$ & $15 / 56(26.8)$ & $8 / 27(29.6)$ \\
\hline \multirow[t]{3}{*}{ Adults } & $\geq 30$ & $25 / 29$ (86.2) & $15 / 18(83.3)$ & $25 / 29(86.2)$ & $15 / 18(83.3)$ \\
\hline & $\geq 70$ & $19 / 29(65.5)$ & $13 / 18(72.2)$ & $19 / 29(65.5)$ & $12 / 18(66.7)$ \\
\hline & $\geq 100$ & $4 / 29(13.8)$ & $4 / 29(13.8)$ & $4 / 18(22.2)$ & $4 / 18(22.2)$ \\
\hline \multirow[t]{2}{*}{ Age group } & & \multicolumn{2}{|c|}{ Inactive disease; n/N (\%) } & \multicolumn{2}{|c|}{ CRP, median; mg/L (n/N) } \\
\hline & & Day 15 & Day 85 & Day 15 & Day 85 \\
\hline Children & & $40 / 216(18.5)$ & $32 / 133(24.1)$ & $12.00(211 / 216)$ & $9.75(168 / 216)$ \\
\hline Adolescents & & 18/56 (32.1) & 10/27 (37.0) & $10.00(55 / 56)$ & $8.40(45 / 56)$ \\
\hline Adults & & $6 / 29(20.7)$ & $8 / 18(44.4)$ & $4.50(26 / 29)$ & $7.80(23 / 29)$ \\
\hline
\end{tabular}

Table 2. Adverse events (AEs)

\begin{tabular}{|l|c|c|c|}
\hline & $\begin{array}{c}\text { Children, } n(\%) \\
\mathrm{N}=233\end{array}$ & $\begin{array}{c}\text { Adolescents, } n(\%) \\
\mathrm{N}=60\end{array}$ & $\begin{array}{c}\text { Adults, } n(\%) \\
\mathrm{N}=31\end{array}$ \\
\hline AEs (at least 1) & $202(86.7)$ & $53(88.3)$ & $27(87.1)$ \\
\hline $\begin{array}{l}\text { AEs leading to study } \\
\text { drug discontinuation }\end{array}$ & $26(11.2)$ & $10(16.7)$ & $6(19.4)$ \\
\hline AEs most common/special interest & $176(75.5)$ & $42(70.0)$ & $23(74.2)$ \\
\hline $\begin{array}{l}\text { Infections and } \\
\text { infestations }\end{array}$ & $122(52.4)$ & $32(53.3)$ & $18(58.1)$ \\
\hline $\begin{array}{l}\text { Gastrointestinal } \\
\text { disorders }\end{array}$ & $119(51.1)$ & $33(55.0)$ & $16(51.6)$ \\
\hline $\begin{array}{l}\text { Musculoskeletal and } \\
\text { connective tissue } \\
\text { disorders }\end{array}$ & $3(1.3)$ & $4(6.7)$ & $1(3.3)$ \\
\hline Opportunistic infections & $11(4.7)$ & $2(3.3)$ & 0 \\
\hline Neutropenia & $81(34.8)$ & $25(41.7)$ & $9(29.0)$ \\
\hline SAE (at least 1) & &
\end{tabular}

Conclusions: Pooled analyses indicate similar efficacy of CAN across all the age grps of children, adolescents and adult SJIA pts. There were no meaningful differences in safety profiles across the different age grp. These analyses suggest similar efficacy of CAN in AOSD pts as observed in the SJIA pts.

\section{References:}

[1] Jamilloux. Immunol Res 2015;61:53-62.

[2] Nirmala. Pediatric Rheumatol 2015;13:50.

Disclosure of Interest: E. Feist Grant/research support from: Novartis, Consultant for: Novartis, P. Quartier Grant/research support from: Abbvie, Novartis, Pfizer, Chugai-Roche, Consultant for: Abbvie, Novartis, Pfizer, Sobi, Roche, Speakers bureau: Abbvie, Novartis, Sobi, Roche, B. Fautrel Grant/research support from: AbbVle, MSD, Pfizer, Consultant for: AbbVie, Biogen, BMS, Celgène, Hospira, Janssen, Lilly, MSD, NORDIC Pharma, Pfizer, Roche, SOBI, UCB, R. Schneider Grant/research support from: Novartis, Consultant for: Novartis, P. Sfriso Consultant for: Novartis, P. Efthimiou: None declared, L. Cantarini Consultant for: Sobi, Novartis, Abbvie, K. Lheritier Employee of: Novartis, K. Leon Employee of: Novartis, C. Karyekar Employee of: Novartis, A. Speziale Employee of: Novartis

DOI: 10.1136/annrheumdis-2017-eular.1979

\section{THU0503 IDENTIFICATION OF OPTIMAL SUBCUTANEOUS (SC) DOSES OF TOCILIZUMAB IN CHILDREN WITH POLYARTICULAR-COURSE JUVENILE IDIOPATHIC ARTHRITIS (PCJIA)}

F. De Benedetti ${ }^{1}$, N. Ruperto ${ }^{2}$, D. Lovell ${ }^{3}$, A.V. Ramanan ${ }^{4}$, R. Cuttica ${ }^{5}$, J.E. Weiss ${ }^{6}$, M. Henrickson ${ }^{3}$, H. Schmeling ${ }^{7}$, J. Anton ${ }^{8}$, K. Minden ${ }^{9}$, J. Hsu ${ }^{10}$, K. Bharucha ${ }^{11}$, S. Wimalasundera ${ }^{12}$, A.K. Kadva ${ }^{11}$, R. Upmanyu ${ }^{12}$, N.L. Mallalieu ${ }^{10}$, A. Martini ${ }^{2}$, H. Brunner ${ }^{3} .{ }^{1}$ IRCCS Ospedale Pediatrico Bambino Gesù, Rome; ${ }^{2}$ PRINTO Coordinating Ctr, Genoa, Italy; ${ }^{3}$ PRCSG, Cincinnati Children's Hosp Med Ctr, Cincinnati, United States; ${ }^{4}$ Bristol Royal Hosp for Children, Bristol, United Kingdom; ${ }^{5}$ Hosp Gral de Niños Pedro Elizalde, Buenos Aires, Argentina; ${ }^{6}$ Hackensack U Med Ctr, Hackensack, United States; ${ }^{7}$ Alberta Children's Hosp/U Calgary, Calgary, Canada; ${ }^{8}$ Hosp Sant Joan de Deu, Barcelona, Spain; ${ }^{9}$ Charité U Med Berlin, Berlin, Germany; ${ }^{10}$ Roche Innovation
Ctr, New York: ${ }^{11}$ Genentech, S San Francisco, United States: ${ }^{12}$ Roche Products Ltd, Welwyn Garden City, United Kingdom

Background: Efficacy and safety of intravenous (IV) tocilizumab (TCZ) have been shown in patients (pts) with pcJIA. ${ }^{1}$

Objectives: Determine appropriate dosing regimens of SC TCZ in pcJIA.

Methods: Pts were aged 1-17 y with pcJIA, inadequate response/intolerance to MTX and TCZ-naive or receiving TCZ IV with adequate disease control. TCZ SC was administered open label by body weight (BW)-based dosing modeled on IV dosing in pcJIA and SC dosing in adult rheumatoid arthritis: pcJIA pts $<30 \mathrm{~kg}$ received TCZ $162 \mathrm{mg}$ every 3 wks (Q3W) and pts $\geq 30 \mathrm{~kg}$ received TCZ $162 \mathrm{mg}$ Q2W for 52 wks. Safety, efficacy (exploratory) and model-computed pharmacokinetic (PK) and pharmacodynamic (PD) parameters were assessed. Results: 52 pts were enrolled; $27<30 \mathrm{~kg}$ and $25>30 \mathrm{~kg} \mathrm{BW;} 85 \%$ and $56 \%$ were TCZ naive. Since no notable difference in steady state PK occurred in naive vs non-naive pts, pooled data are shown. Median $\mathrm{C}_{\min }$ was similar between $\mathrm{BW}$ groups and higher than with TCZ IV (TCZ IV median $\mathrm{C}_{\min }: 3.2 \mu \mathrm{g} / \mathrm{mL}$ for $10 \mathrm{mg} / \mathrm{kg}$ $<30 \mathrm{~kg} \mathrm{BW}$ and $7.3 \mu \mathrm{g} / \mathrm{mL}$ for $8 \mathrm{mg} / \mathrm{kg} \geq 30 \mathrm{~kg} \mathrm{BW}$ ) ensuring adequate exposure from SC doses. Median $\mathrm{C}_{\max }$ was lower from SC than IV dosing. Changes in PD parameters for TCZ-naive pts were consistent with those for TCZ IV. JADAS-71 generally improved (Table), with trends consistent with those for TCZ IV. Infections were the most frequent adverse event (AE), reported in $36 \mathrm{pts} ; 2$ serious infections occurred in 1 pt. Injection site reactions occurred in $15 \%$ pts in the $<30 \mathrm{~kg}$ group and $44 \%$ pts in the $\geq 30 \mathrm{~kg}$ group. The most common symptoms were erythema, swelling, hematoma, pain and pruritus. No serious hypersensitivity, AE leading to withdrawal, opportunistic infection, serious hepatic AE or death occurred. Overall there were 4 serious AEs in 3 pts $(7.9 / 100$ pt-y, consistent with that for TCZ IV).

\begin{tabular}{|c|c|c|}
\hline & $\begin{array}{l}\text { TCZ 162mg SC Q3W, } \\
\text { BW <30kg (n=27) }\end{array}$ & $\begin{array}{c}\text { TCZ 162mg SC Q2W, } \\
B W \geq 30 \mathrm{~kg}(\mathrm{n}=25)\end{array}$ \\
\hline \multicolumn{3}{|c|}{ ameters, median [range] } \\
\hline & $13.4[0.2,52.3]$ & $12.7[0.2,23.8]$ \\
\hline & 62.4 & $0.3]$ \\
\hline $\mathrm{AUC}_{12 \text { weeks }}, \mu \mathrm{g} / \mathrm{mL} \times$ day & $2998[1465,7708]$ & $1933[324,3098]$ \\
\hline \multicolumn{3}{|c|}{ Change from baseline to week $52^{\mathrm{a}}$ in PD markers and efficacy, median [range]; TCZ-naive pts } \\
\hline $\mathrm{IL}-6, \mathrm{pg} / \mathrm{mL}$ & $27.3[3.5,173.9], n=11$ & $12.2[-6.2,30.9], n=9$ \\
\hline & $612.1[399.4,808.4], \mathrm{n}=14$ & $429.3[245.5,585.6], \mathrm{n}=11$ \\
\hline & $-1.3[-1$ & $-0.8[-22.9,0.0], \mathrm{n}=12$ \\
\hline & $-11.0[-40.0,0.0], n=21$ & $-6.0[-35.0,0.0], n=12$ \\
\hline JADAS-71 & $-16.8[-40.3,-4.4], \mathrm{n}=21$ & $-12.9[-48.1,-2.3], \mathrm{n}=12$ \\
\hline
\end{tabular}

a Week 51 for Q3W group. AUC, area under the concentration curve; CRP, C-reactive protein; ESR, erythrocyte sedimentation rate; IL-6, interleukin-6; sIL-6R, soluble IL-6 receptor.

Conclusions: The BW-based TCZ SC dosing regimens for pcJIA provided adequate exposure to support efficacy comparable to that for TCZ IV, with an acceptable benefit-risk profile.

\section{References:}

[1] Brunner HI et al. Ann Rheum Dis 2014;74:1110-7.

Disclosure of Interest: F. De Benedetti Grant/research support from: Novartis, Roche, Pfizer, SOBI, AbbVie, Novimmune, BMS, Sanofi, N. Ruperto Consultant for: AbbVie, Amgen, Alter, AstraZeneca, Baxalta Biosimilars, Biogenidec, Boehringer, BMS, Celgene, CrescendoBio, EMD Serono, Hoffmann-La Roche, Italfarmaco, Janssen, Medlmmune, Medac, Novartis, Novo Nordisk, Pfizer, Sanofi Aventis, Servier, Takeda, UCB Biosciences GmbH, Speakers bureau: AbbVie, Amgen, Alter, AstraZeneca, Baxalta Biosimilars, Biogenidec, Boehringer, BMS, Celgene, CrescendoBio, EMD Serono, Hoffmann-La Roche, Italfarmaco, Janssen, Medlmmune, Medac, Novartis, Novo Nordisk, Pfizer, Sanofi Aventis, Servier, Takeda, UCB Biosciences GmbH, D. Lovell Grant/research support from: NIH, NIAMS, Consultant for: Astra-Zeneca, Bristol Meyers Squibb, AbbVie, Pfizer, Roche, Novartis, UBC, Forest Research Institute, Horizon, Johnson \& Johnson, Biogen, Takeda, Genentech, GlaxoSmithKline, Boehringer Ingelheim, Celgene, Janssen, A. Ramanan Speakers bureau: Roche, AbbVie, R. Cuttica Consultant for: Roche, Novartis, Lilly, GlaxoSmithKline, Bristol-Myers Squibb, Janssen, Speakers bureau: Roche, Novartis, Lilly, GlaxoSmithKline, Bristol-Myers Squibb, Janssen, J. Weiss: None declared, M. Henrickson: None declared, H. Schmeling Grant/research support from: Janssen, Pfizer, UCB Biosciences $\mathrm{GmbH}$, J. Anton Grant/research support from: Roche, K. Minden Grant/research support from: AbbVie, Pfizer, Roche, Speakers bureau: AbbVie, Pfizer, Roche, Genzyme, Pharm-Allergan, J. Hsu Employee of: Roche, K. Bharucha Employee of: Genentech, S. Wimalasundera Employee of: Roche Products Ltd., A. Kadva Employee of: Genentech, R. Upmanyu Employee of: Roche Products Ltd., N. Mallalieu Shareholder of: Roche, Employee of: Roche, A. Martini Consultant for: Abbvie, Boehringer, Celgene, CrescendoBio, Janssen, Medlmmune, Novartis, NovoNordisk, Pfizer, Sanofi Aventis, Vertex, Servier, Speakers bureau: Abbvie, Boehringer, Celgene, CrescendoBio, Janssen, Medlmmune, Novartis, NovoNordisk, Pfizer, Sanofi Aventis, Vertex, Servier, H. Brunner: None declared DOI: 10.1136/annrheumdis-2017-eular.2483 